\title{
MEMOIRS
}

\section{JULIAN ANTONY SEVERN LAMB}

TONY LAM B died as the result of an accident on 19 March 1973, at the age of 56.

His business career was spent entirely in the insurance world, beginning in 1936. Career and actuarial studies were interrupted by six years' war service in the Royal Artillery. Resuming. both in 1945, Lamb qualified as a Fellow of the Institute in 1947 and moved to the Royal London Mutual Insurance Society in 1949. The Royal London was to provide the remainder of his business career, which was marked by rapid progress. Within six years he had been appointed Actuary to the Society. In 1965 he was elected to the Board of Directors, and five years later he relinquished the post of Actuary to become a General Manager. Appointment as the Society's Chief General Manager followed in 1972.

Lamb gave long service to the life assurance industry. He was a member of the Executive of the Industrial Life Offices Association, of the Industrial Assurance Council, and of several committees of the Life Offices' Association. These latter included the joint committee of the LOA and the Associated Scottish Life Offices dealing with public relations. Because he naturally put people before things and because he recognized that wise and skilful communication are essential to success and efficiency in any business activity, he took to PR work with enthusiasm. It was during his period as Chairman of this committee that he played a leading part in the establishment, by the Life Office Associations and the British Medical Association, of the British Life Assurance Trust for Health Education. The purpose and outward-looking philosophy of the Trust appealed greatly to him and he retained a strong interest in its activities and development. Only some two months before his death he was elected Deputy Chairman of the Life Offices' Association.

Lamb's work for the Institute began in 1950 as a tutor, followed after four years by a similar period as an examiner. He was elected to Council in 1967 and re-elected in 1972. His membership of dining clubs included office as Secretary and as Chairman of the Denarius Club, as Secretary of the Fellowship Club, and as Chairman of the Fifty Nine Club, of which he was a founder-member.

This bare account of a busy, successful career, cut short just as it was coming to new heights of recognition and authority, would be incomplete without reference to Tony Lamb the man, husband and father. Apart from his interests in music, photography, gardening and the Field Survey Association, his knack of becoming involved in unusual incidents afforded him many opportunities for exploiting his considerable talent for anecdote (often told against himself) and this, coupled with his strong personality and ready wit, resulted in his bringing many a cheerful element of colour into other people's lives. He was an evidently affectionate family man, proud of his children; and his Dutch wife, known to all as Jean, and his daughter and two sons all have the sympathy of his many friends and colleagues. Tony Lamb himself will be remembered with affection and respect by all who knew him, in working time or leisure time.

ALFRED EDWARDS

\section{HENRY JOHN TAPPENDEN}

Sоме lives have a tragic quality almost Greek in intensity. Harry Tappenden's life was one; he suffered much, but bore his suffering with great courage. He was born in January 1906; his early life was spent in Orpington and he retained a great affection for this place, as he did for the City of London School where he was educated.

His whole career was spent with The Equitable Life Assurance Society, which he joined in 1922. For a while he served with the subsidiaries transacting reversionary business, becoming Actuary and Secretary of both subsidiaries in 1934. He was appointed Deputy Manager of the 